\title{
Pengelolaan Kelas dalam Pembelajaran
}

\author{
Zainal Azman
}

STAI Bumi Silampari Lubuklinggau

zainalazman@staibsllg.ac.id

\begin{tabular}{|c|c|}
\hline Abstrak & \\
\hline $\begin{array}{l}\text { Article History } \\
\text { Received:16 November } 2019 \\
\text { Revised : } 20 \text { November } 2019 \\
\text { Accepted:26 Desember } 2019\end{array}$ & $\begin{array}{l}\text { Classroom management is a } \\
\text { conscious effort to regulate the } \\
\text { activities of the teaching and } \\
\text { learning process systematically }\end{array}$ \\
\hline $\begin{array}{l}\text { Keywords: } \\
\text { Classroom } \quad \text { management, } \\
\text { learning }\end{array}$ & $\begin{array}{l}\text { which leads to the preparation of } \\
\text { facilities and teaching aids, the } \\
\text { arrangement of the learning space, } \\
\text { realizing the situation or condition } \\
\text { of the teaching and learning } \\
\text { process going well and the } \\
\text { curricular objectives can be } \\
\text { achieved. The ultimate goal of } \\
\text { classroom management is students } \\
\text { can develop self-discipline. } \\
\text { Therefore, teachers should always } \\
\text { encourage students to carry out } \\
\text { self-discipline and the teacher } \\
\text { himself should be an example of } \\
\text { self-control and the implementation } \\
\text { of responsibilities. So, teachers } \\
\text { must be disciplined in everything if } \\
\text { they want their students to be } \\
\text { disciplined in everything. }\end{array}$ \\
\hline
\end{tabular}

\section{Pendahuluan}

Dunia pendidikan kita dewasa ini menghadapi berbagai masalah yang amat kompleks dan semua itu memerlukan perhatian kita semua. Salah satu diantaranya adalah perhatian kita terhadap pengelolaan kelas. Kelas sebagai basis pengajaran di garis depan adalah tempat berlangsung interaksi antara guru dengan murid secara nyata. Interaksi ini bermuatan pendidikan apabila guru merancang interaksinya secara pedagogis dapat dipertanggungjawabkan. Maksud secara pedagogis adalah upaya bertanggung jawab dari guru untuk 
mengantarkan peserta didik untuk mencapai tujuan pendidikan yang telah digariskan.

Pembahasan tentang pengelolaan kelas merupakan suatu hal yang sangat penting, baik masa sekarang maupun masa yang akan datang. Mulai dari hal-hal yang sederhana seperti masalah ruang kelas, kursi, meja, lemari, alat-alat tulis dan lain sebagainya, sampai kepada hal-hal yang berkaitan dengan bagaimana merancang tata letak yang pedagogis, bagaimana pemanfaatan media sebagai media pembelajaran yang semuanya itu termasuk dalam bidang pengelolaan kelas.

Bagi guru yang telah memiliki pengalaman mengajar cukup lama tidak terlalu kesulitan dalam mengelola kelas pada waktu berlangsungnya proses pembelajaran. Namun bagi guru yang baru mengajar tentunya masih perlu upaya keras dalam penerapan pendekatan-pendekatan pengelolaan kelas. Pada lembaga pendidikan nonformal seperti Taman Pendidikan Al-Qur'an (TPA), peluang terjadinya hal-hal yang tidak sesuai dengan ketentuan-ketentuan manajemen kelas, terutama bagi gurunya yang tidak berlatar belakang pendidikan atau pengalaman pengelolaan kelas yang sesuai dengan asas dedaktik. Akhirnya proses interaksi belajar mengajar yang dikembangkan penuh sesak dengan transfer pengetahuan, tapi minim transfer kepribadian.

Merupakan upaya yang strategis apabila perbaikan pendidikan dimulai dari memperbaiki interaksi guru dengan murid di dalam kelas. Hal ini sejalan dengan konsep desentralisasi pendidikan yang mengedepankan kemandirian guru dalam membangun interaksi dengan peserta didik melalui proses pembelajaran.

\section{Metode Penerlitian}

Penelitian ini adalah penelitian kualitatif yang bersifat studi pustaka (library research) yang menggunkan buku-buku dan literatur-literatur lainnya sebagai objek yang utama (Hadi, 2001: 3) jenis penelitian yang digunakan adalah kualitatif, yaitu penelitian yang menghasilkan informasi berupa catatan dan data deskriptif yang terdapat di dalam teks yang diteliti (Mantra, 2008: 30). Analisis data berupa analisis isi (content analysis). Penelitian ini menganalisis bahan pemikiran tentang Pengelolaan Kelas dalam Pembelajaran. 


\section{Pengelolaan Kelas}

\section{Pengertian pengelolaan kelas}

Pengelolaan kelas terdiri dari dua kata, yaitu pengelolaan dan kelas. "Pengelolaan itu sendiri akar katanya adalah "kelola", ditambah awalan "pe" dan akhiran "an". Istilah lain dari pengelolaan adalah "manajemen". Manajemen adalah kata yang aslinya dari bahasa Inggris, yaitu management yang berarti ketatalaksanaan, tata pimpinan, pengelolaan" (Djamarah, 210:175)

Pengelolaan adalah "proses yang memberikan pengawasan pada semua hal yang terlibat dalam pelaksanaan kebijakan dan pencapaian tujuan". Pengelolaan dalam pengertian umum menurut Arikunto yang dikutip Djamarah (210:176) adalah "pengadministrasian pengaturan atau penataan suatu kegiatan". Menurut Hamalik yang dikutip Djamarah kelas adalah "suatu kelompok orang yang melakukan kegiatan belajar bersama yang mendapat pengajaran dari guru". Hadari Nawawi (1989:175) memandang kelas dari dua sudut, yaitu: "kelas dalam arti yang sempit dan kelas dalam arti yang luas".

Kelas dalam arti yang sempit yakni, ruangan yang dibatasi oleh empat dinding, tempat sejumlah siswa berkumpul untuk mengikuti proses belajar mengajar. Kelas dalam pengertian tradisional ini mengandung sifat statis karena menunjuk pengelompokan siswa menurut tingkat perkembangan yang antara lain didasarkan pada batas umur kronologis masing-masing.

Kelas dalam arti luas adalah suatu masyarakat kecil yang merupakan bagian dari masyarakat sekolah yang sebagai suatu kesatuan diorganisasi menjadi unit kerja yang secara dinamis menyelenggarakan kegiatan-kegiatan belajar mengajar yang kretif untuk mencapai suatu tujuan. Menurut Made Pidarta (Djamarah, 2010:172) bahwa yang dimaksud pengelolaan kelas adalah "proses seleksi dan penggunaan alat-alat yang tepat terhadap problem dan situasi kelas". Guru bertugas menciptakan, memperbaiki, dan memelihara sistem atau organisasi kelas. Sehingga anak didik dapat memanfaatkan kemampuannya, bakat dan energinya pada tugas-tugas individual. Sudirman (1991:310) mengatakan bahwa pengelolaan kelas "merupakan upaya dalam memperdayagunakan potensi kelas". Kelas merupakan peranan dan fungsi tertentu dalam menunjang keberhasilan proses interaksi edukatif, agar memberikan dorongan dan rangsangan terhadap 
anak didik untuk belajar, kelas harus dikelola sebaik-baiknya oleh guru.

Pengelolaan kelas merupakan keterampilan guru untuk menciptakan iklim pembelajaran yang kondusif dan mengendalikannya jika terjadi gangguan dalam pembelajaran. Sedangkan menurut Sudirman yang dikutip oleh Djamarah berpedapat bahwa "Pengelolaan kelas asalah upaya mendayagunakan potensi kelas". Ditambahkan lagi oleh Nawai yang dikutip oleh Djamarah (2010:177) berpendapat bahwa "Manajemen atau pengelolaan kelas dapat diartikan sebagai kemampuan guru dalam mendayagunakan potensi kelas berupa pemberian kesempatan yang seluas-luasnya pada setiap personal untuk melakukan kegiatan-kegiatanya yang kreatif dan terarah".

Menurut Arikunto yang dikutip Djamarah berpendapat bahwa pengelolaan kelas adalah "suatu usaha yang dilakukan oleh penanggung jawab kegiatan belajar mengajar atau yang membantu dengan maksud agar dicapai kondisi optimal sehingga dapat terlaksana kegiatan belajar yang seperti diharapkan". Menurut Saefullah (2014:2) Manajemen adalah proses perencanaan, pengorganisasian, kepemimpinan, dan pengendalian upaya anggota organisasi dengan menggunakan semua sumber daya organisasi untuk mencapai tujuan yang telah ditetapkan.

Berdasar pendapat para ahli di atas, maka dapat disimpulkan bahwa pengelolaan kelas merupakan usaha sadar untuk mengatur kegiatan proses belajar mengajar secara sistematis yang mengarah pada penyiapan sarana dan alat peraga, pengaturan ruang belajar, mewujudkan situasi atau kondisi proses belajar mengajar berjalan dengan baik dan tujuan kurikuler dapat tercapai.

\section{Tujuan dan prinsip dalam manajemen kelas}

Tujuan manajemen kelas pada hakikatnya telah terkandung dalam tujuan pendidikan. Secara umum pengelolaan kelas adalah penyedian fasilitas bagi bermacam macam kegiatan belajar siswa dalam lingkungan sosial, emosional, dan intelektual dalam kelas. Fasilitas yang demikian itu memungkinkan siwa belajar dan bekerja, terciptanya suasana sosial yang memberikan kepuasan, suasana disiplin, perkembangan intelektual, emosional dan sikap serta apresiasi pada siswa. (Sudirman N, 1991, 311). Suharsimi 
Arikunto (1988 : 68) berpendapat bahwa tujuan pengelolaan kelas adalah agar setiap anak di kelas dapat bekerja dengan tertib sehingga tercapai tujuan pengajaran secara efektif dan efisien.

Terkait dari penjelasan diatas dalam hal pengelolaan kelas dapat pula ditinjau dari segi interaksi komunikatif. Artinya seorang guru dituntut mampu mengatur segala kondisi apapun yang terjadi didalam kelas saat pebelajaran berlangsung agar terciptanya komunikasi dua arah yaitu antara guru dengan murid, murid dengan guru sehingga proses belajar-mengajar dapat berlangsung dengan baik. Hal ini bertujuan untuk memudahkan sekaligus meringankan tugas guru atau wali kelas. Untuk memperkecil masalah gangguan dalam kelas, prinsipprinsip pengelolaan kelas dapat dipergunakan. Sehingga guru harus mengetahui dan menguasai prinsip-prinsip pengelolaan kelas, yang diuraikan berikut ini:

a. Hangat dan Antusias

Hangat dan antusias diperlukan dalam proses belajar mengajar.guru yang hangat dan akrab dengan anak didik selalu menunjukkan antusias pada tugasnya atau pada aktivitasnya akan berhasil dalam mengimplementasikan pengelolaan kelas.

b. Tantangan

Penggunaan kata-kata, tindakan, cara kerja atau bahan-bahan yang menantang akan meningkatkan gairah anak didik untuk belajar sehingga mengurangi kemungkinan munculnya tingkah laku yang menyimpang.

c. Bervariasi

Penggunaan alat atau media atau alat bantu,gaya mengajar guru, pola interaksi antara guru dan anak didik mengurangi munculnya gangguan, kevariasian dalam penggunaan media merupakan kunci untuk tercapainya pengelolaan kelas yang efektif.

d. Keluesan

Keluesan tingkah laku guru untuk mengubah strategi mengajarnya dapat mencegah kemungkinan munculnya gangguan anak didik serta menciptakan iklim belajar mengajar yang efektif.

e. Penekanan pada hal-hal yang positif 
Pada dasarnya, dalam mengajar dan mendidik, guru harus menekankan pada hal-hal yang positif, dan menghindari pemusatan perhatian anak didik pada hal-hal yang negatif. Penekanan tersebut dapat dilakukan dengan pemberian penguatan yang positif, dan kesadaran guru untuk menghindari kesalahan yang dapat mengganggu jalannya proses belajar mengajar.

f. Penanaman disiplin diri

Tujuan akhir dari pengelolaan kelas adalah anak didik dapat mengembangkan disiplin diri sendiri. Karena itu,guru sebaiknya selalu mendorong anak didik untuk melaksanakan disiplin diri sendiri dan guru sendiri hendaknya menjadi teladan mengenai pengendalian diri dan pelaksanaan tanggung jawab. Jadi, guru harus disiplin dalam segala hal bila ingin anak didiknya iku disiplin berdisiplin dalam segala hal.

\section{Permasalahan dalam Manajemen Kelas}

Ada dua jenis masalah pengelolaan kelas, yaitu yang bersifat perorangan atau individual dan yang bersifat kelompok. Disadari bahwa masalah perorangan atau individual dan masalah kelompok seringkali menyatu dan amat sukar dipisahkan yang satu dari yang lain. Namun demikian, pembedaan antara kedua jenis masalah itu akan bermanfaat, terutama apabila guru ingin mengenali dan menangani permasalahan yang ada dalam kelas yang menjadi tanggungjawabnya.

1. Masalah Individual

Penggolongan masalah individual ini didasarkan atas anggapan dasar bahwa tingkah laku manusia itu mengarah pada pencapaian suatu tujuan. Setiap individu memiliki kebutuhan dasar untuk memiliki dan untuk merasa dirinya berguna. Jika seorang individu gagal mengembangkan rasa memiliki dan rasa dirinya berharga maka dia akan bertingkah laku menyimpang. Ada empat jenis penyimpangan tingkah laku, yaitu:

a. Tingkah laku menarik perhatian orang lain,

Seorang siswa yang gagal menemukan kedudukan dirinya secara wajar dalam suasana hubungan sosial yang saling menerima biasanya (secara aktif ataupun pasif) bertingkah laku mencari perhatian orang lain. Tingkah laku destruktif pencari perhatian yang aktif dapat dijumpai pada anak-anak yang suka 
pamer, melawak(memperolok), membuat onar, memperlihatkan kenakalan, terus menerus bertanya; singkatnya, tukang rewel. Tingkah laku destruktif pencari perhatian yang pasif dapat dijumpai pada anak-anak yang malas atau anak-anak yang terus meminta bantuan orang lain

b. Mencari kekuasaan,

Tingkah laku mencari kekuasaan sama dengan perhatian yang destruktif, tetapi lebih mendalam. Pencari kekuasaan yang aktif suka mendekat, berbohong, menampilkan adanya pertentangan pendapat, tidak mau melakukan yang diperintahkan orang lain dan menunjukkan sikap tidak patuh secara terbuka. Pencari kekuasaan yang pasif tampak pada anak-anak yang amat menonjolkan kemalasannya sehingga tidak melakukan apa-apa sama sekali. Anak-anak ini amat pelupa, keras kepala, dan secara pasif memperlihatkan ketidakpatuhan

c. Menuntut balas

Siswa yang menuntut balas mengalami frustasi yang amat dalam dan tidak menyadari bahwa dia sebenarnya mencari sukses dengan jalan menyakiti orang lain. Keganasan, penyerangan secara fisik (mencakar, menggigit, menendang) terhadap sesama siswa, petugas atau pengusaha, ataupun terhadap binatang sering dilakukan anak-anak ini. Anak-anak seperti ini akan merasa sakit kalau dikalahkan, dan mereka bukan pemain-pemain yang baik (misalnya dalam pertandingan). Anak-anak yang suka menuntut balas ini biasanya lebih suka bertindak secara aktif daripada pasif.Anakanak penuntut balas yang aktif sering dikenal sebagai anakanak yang ganas dan kejam, sedang yang pasif dikenal sebagai anak-anak pencemberut dan tidak patuh (suka menetang).

d. Memperlihatkan ketidakmampuan.

Siswa yang memperlihatkan ketidakmampuan pada dasarnya merasa amat tidak mampu berusaha mencari sesuatu yang dikehendakinya (yaitu rasa memiliki) yang bersikap menyerah terhadap tantangan yang menghadangnya; bahkan siswa ini menganggap bahwa yang ada dihadapannya hanyalah kegagalan yang terus menerus.Perasaan tanpa harapan dan tidak tertolong lagi ini biasanya diikuti dengan tingkah laku mengundurkan atau memencilkan diri.Sikap yang memperlihatkan ketidakmampuan ini selalu berbentuk pasif. 
Keempat masalah individual tersebut akan tampak dalam berbagai bentuk tindakan atau perilaku menyimpang, yang tidak hanya akan merugikan dirinya sendiri tetapi juga dapat merugikan orang lain atau kelompok. Ada empat teknik sederhana untuk mengenali adanya masalah-masalah individu seperti diuraikan diatas pada diri para siswa. Diantaranya yaitu :

a. Jika guru merasa terganggu (atau bosan) dengan tingkah laku seorang siswa, hal itu merupakan tanda bahwa siswa yang bersangkutan mungkin mengalami masalah mencari perhatian.

b. Jika guru merasa terancam (atau merasa dikalahkan), hal itu merupakan tanda bahwa siswa yang bersangkutan mungkin mengalami masalah mencari kekuasaan.

c. Jika guru merasa amat disakiti, hal itu merupakan tanda bahwa siswa yang bersangkutan mungkin mengalami masalah menuntut balas.

d. Jika guru merasa tidak mampu menolong lagi, hal itu merupakan tanda bahwa siswa yang bersangkutan mungkin mengalami masalah ketidakmampuan. Ditekankan, guru hendaknya benar-benar mampu mengenali dan memahami secara tepat arah tingkah laku siswa-siswa yang dimaksud (apakah tingkah laku siswa itu mengarah ke mencari perhatian, mencari kekuasaan, menuntut balas, atau memperlihatkan ketidakcampuran) agar guru itu mampu menangani masalah siswa secara tepat pula.

2. Masalah Kelompok

Berdasarkan pengalaman guru di lapangan. Masalah-masalah yang timbul di dalam pelaksanaan pengajaran dapat diidentifikasikan sebagai berikut:

a. Masalah pengarahan

Di waktu merencanakan, melaksanakan dan mengevaluasi proses belajar-mengajar, kebanyakan guru kurang memiliki keterampilan dalam:

1) Berorientasi kepada tujuan pelajaran.

2) Mengkomunikasikan tujuan pelajaran kepada siswa.

3) Memahami cara merumuskan tujuan umum dan khusus.

4) Menyesuaikan tujuan pelajaran dengan kemampuan dan kebutuhan siswa.

5) Merumuskan tujuan instruksional jelas. 
Keadaan ini mengakibatkan secara jelas terhadap tujuan mempelajari materi tersebut, mereka tidak mendapat kepuasan dalam menerima pelajaran, siswa menyadari bahwa tujuan pelajaran yang diberikan guru tidak relevan dengan kebutuhannya tidak bermakna bagi kehidupannya di kemudian hari.

b. Masalah evaluasi dan penilaian

Guru dalam tugasnya untuk merencanakan, melaksanakan evaluasi dan menemukan masalah-masalah sebagai berikut:

1) Guru dalam menyusun kriteria keberhasilan tidak jelas

2) Prosedur evaluasi tidak jelas

3) Guru tidak melaksanakan prinsip-prinsip evaluasi yang efisien dan efektif.

4) Kebanyakan guru memiliki cara penilaian yang tidak seragam.

5) Guru kurang menguasai teknik-teknik evaluasi.

6) Guru tidak memanfaatkan analisa hasil evaluasi sebagai bahan umpan balik.

Dengan evaluasi yang semacam itu siswa yang menerima evaluasi tidak puas. Mereka tidak mengerti arti angka-angka yang diterimanya. Guru juga tidak mengetahui apakah muridnya sudah mempelajari materi pelajaran yang diberikan atau belum. Guru tidak mengerti bahwa pada siswa sudah ada perubahan tingkah laku, sebagai pengaruh pengajaran yang diberikan atau tidak.

c. Masalah isi dan urut-urutan pelajaran

Dalam membuat perencanaan pengajaran, yang kemudian akan dilaksanakan dan dievaluasi, guru dalam menyusun isi dan urutan bahan pelajaran menemukan masalah sebagai berikut:

1) Guru kurang menguasai materi

2) Materi yang disajikan tidak relevan dengan tujuan

3) Materi yang diberikan sangat luas

4) Guru kurang mampu dalam menyesuaikan penyajian bahan dengan waktu yang tersedia

5) Guru kurang terampil dalam mengorganisasikan materi pelajaran. 
6) Guru kurang mampu mengembangkan materi pelajaran yang diberikannya.

7) Guru kurang mempertimbangkan urutan tingkat kesukaran dari materi pelajaran yang diberikan.

e. Masalah metode dan sistem penyajian bahan pelajaran

Agar guru dapat menyajikan bahan pelajaran dengan menarik dan berhasil, maka perlu menguasai beberapa teknik sistem penyajian. Juga dapat memilih siswa penyajian yang tepat untuk setiap materi tertentu yang akan disajikan, ataupun dapat membuat variasi dalam menyajikan bahan tersebut. Namun dengan demikian dalam pengamatan pelaksanaan pengajaran itu para guru menemukan masalah-masalah sebagai berikut:

1) Guru kurang menguasai beberapa siswa penyajian yang menarik dan efektif.

2) Pemilihan metode kurang relevan dengan tujuan pelajaran dan materi pelajaran.

3) Kurang terampil dalam menggunakan metode

4) Sangat terikat pada satu metode saja

5) Guru tidak memberikan umpan balik pada tugas yang dikerjakan siswa.

e. Masalah hambatan-hambatan

Dalam pelaksanaan pengajaran guru kadang-kadang menemui banyak hambatan, diantaranya ialah:

1) Banyak guru kurang menggunakan perpustakaan sebagai sumber belajar.

2) Guru kurang mempertimbangkan latar belakang siswa yang tidak sama.

3) Guru kurang mengerti tentang kemampuan dasar siswa yang kurang.

4) Kurangnya buku-buku bacaan ilmiah

5) Keadaan sarana yang kurang

6) Guru kurang mampu dalam menguasai bahasa Inggris.

Dengan banyaknya hambatan-hambatan akan mengakibatkan pengajaran menjadi kurang lancar. Guru mengalami kesulitan dalam meningkatkan proses belajar mengajar agar hasilnya efektif dan efisien. Begitu juga siswa sendiri kurang 
bersemangat untuk mendalami setiap bagian pengetahuan yang diperolehnya di bangku sekolah.

\section{Solusi dalam Memecahkan Masalah Pengelolaan Kelas}

Upaya yang harus dilakukan dalam mengatasi masalah dalam pengelolaan kelas di atas, ada beberapa pendekatan yang dapat dilakukan, diantaranya sebagai berikut:

1. Behavior - Modification Approach (Behaviorism Apparoach) :

Asumsi yang mendasari penggunaan pendekatan ini adalah bahwa perilaku "baik" dan "buruk" individu merupakan hasil belajar.Upaya memodifikasi perilaku dalam mengelola kelas dilakukan melalui pemberian positive reinforcement (untuk membina perilaku positif) dan negative reinforcement (untuk mengurangi perilaku negatif). Namun demikian, dalam penggunaan reinforcement negatif seyogyanya dilakukan secara hati-hati, karena jika tidak tepat malah hanya akan menimbulkan masalah baru.

2. Socio-Emotional Climate Approach (Humanistic Approach) :

Asumsi yang mendasari penggunaan pendekatan ini adalah bahwa proses belajar mengajar yang baik didasari oleh adanya hubungan interpersonal yang baik antara peserta didik - guru dan atau peserta didik - peserta didik dan guru menduduki posisi penting bagi terbentuknya iklim sosio-emosional yang baik. Dalam hal ini, Carl A. Rogers mengemukakan pentingnya sikap tulus dari guru (realness, genuiness, congruence); menerima dan menghargai peserta didik sebagai manusia (acceptance, prizing, caring, trust) dan mengerti dari sudut pandangan peserta didik sendiri (emphatic understanding). Sedangkan Haim C. Ginnot mengemukakan bahwa dalam memecahkan masalah, guru berusaha untuk membicarakan situasi, bukan pribadi pelaku pelanggaran dan mendeskripsikan apa yang ia lihat dan rasakan; serta mendeskripsikan apa yang perlu dilakukan sebagai alternatif penyelesaian. Selain itu juga dikemukakan William Glasser bahwa guru sebaiknya membantu mengarahkan peserta didik untuk mendeskripsikan masalah yang dihadapi; menganalisis dan menilai masalah; menyusun rencana pemecahannya; mengarahkan peserta didik agar committed terhadap rencana yang telah dibuat memupuk keberanian menanggung akibat "kurang menyenangkan"; serta membantu peserta didik membuat 
rencana penyelesaian baru yang lebih baik. Sementara itu, Rudolf Draikurs mengemukakan pentingnya Democratic Classroom Process, dengan memberikan kesempatan kepada peserta didik untuk dapat memikul tanggung jawab; memperlakukan peserta didik sebagai manusia yang dapat secara bijak mengambil keputusan dengan segala konsekuensinya; dan memberi kesempatan kepada peserta didik untuk menghayati tata aturan masyarakat

3. Group Process Approach

Asumsi yang mendasari penggunaan pendekatan ini adalah bahwa pengalaman belajar berlangsung dalam konteks kelompok sosial dan tugas guru adalah membina dan memelihara kelompok yang produktif dan kohesif. Richard A. Schmuck \& Patricia A. Schmuck mengemukakan prinsip - prinsip dalam penerapan pendekatan group proses, yaitu : (a) mutual expectations; (b) leadership; (c) attraction (pola persahabatan); (c) norm; (d) communication; (d) cohesiveness.

4. Pendekatan Otoriter

Pandangan yang otoriter dalam pengelolaan kelas merupakan seperangkat kegiatan guru untuk nienciptakan dan mempertahankan ketertiban suasana kelas. Pengelolaan kelas sebagai proses untuk mengontrol tingkah laku siswa ke arah disiplin. Bila timbul masalah-masalah yang merusak ketertiban atau kedisplinan kelas, maka perlu adanya pendekatan:

a. Perintah dan larangan

b. Penekanan dan penguasaan

c. Penghukuman dan pengancaman

d. Pendekatan perintah dan larangan

5. Pendekatan Permisif

Pendekatan permisif dalam pengelolaan kelas merupakan seperangkat kegiatan pengajar yang memaksimalkan kebebasan peserta didik untuk melakukan sesuatu.Sehingga bila kebebasan ini dihalangi dapat menghambat perkembangan peserta didik. Berbagai bentuk pendekatan dalam pelaksanaan pengelolaan kelas ini banyak menyerahkan segala inisiatif dan tindakan pada diri peserta didik. Diantaranya yaitu sebagai berikut: 
a. Tindakan pendekatan pengalihan merupakan tindakan yang bersifat premisif. Dari tindakan pendekatan ini muncul halhal yang kurang disadari oleh peserta didik.

b. Meremehkan sesuatu kejadian, atau tidak melakukan apa-apa sama sekali

c. Memberi peluang kemalasan dan menunda pekerjaan.

d. Menukar dan mengganti susunan kelompok tanpa melalui prosedur yang sebenarnya.

e. Menukar kegiatan salah satu pembelajar, digantikan oleh orang lain.

f. Mengalihkan tanggung jawab kelompok kepada seorang anggota

6. Pendekatan membiarkan dan memberi kebebasan

Pengajar memandang peserta didik telah mampu melakukan sesuatu dengan prosedur yang benar."Biarlah mereka bekerja sendiri dengan bebas", demikian pegangan pengajar dalam mengelola kelas. Lebih kurang menguntungkan lagi kalau selama peserta didik bekerja sendiri, pengajar juga aktif mengerjakan tugas sendiri dan pada saat waktu habis baru ditanyakan atau disusun.

\section{Penutup}

Pengelolaan kelas merupakan usaha sadar untuk mengatur kegiatan proses belajar mengajar secara sistematis yang mengarah pada penyiapan sarana dan alat peraga, pengaturan ruang belajar, mewujudkan situasi atau kondisi proses belajar mengajar berjalan dengan baik dan tujuan kurikuler dapat tercapai.

Tujuan akhir dari pengelolaan kelas adalah anak didik dapat mengembangkan disiplin diri sendiri. Karena itu,guru sebaiknya selalu mendorong anak didik untuk melaksanakan disiplin diri sendiri dan guru sendiri hendaknya menjadi teladan mengenai pengendalian diri dan pelaksanaan tanggung jawab. Jadi, guru harus disiplin dalam segala hal bila ingin anak didiknya iku disiplin berdisiplin dalam segala hal. 
64 Zainal Azman, Pengelolaan Kelas dalam .....

\section{DAFTAR PUSTAKA}

Almasawi,dkk. 2010. Masalah-masalah dalam Manajemen Kelas.

Ekosiswoyo, Rasdi. 2000. Manajemen Kelas. Semarang: CV. Ikip.Semarang press.

Bahri Djamarah. 2000. Syaiful. Strategi Belajar Mengajar. Jakarta, Rineka Cipta.

Fthurrohman. Pupuh. 2014. Strategi Belajar Mengajar: Strategi Mewujudkan Pembelajaran Bermakna Melalui Pemahaman Konsep Umum \& Islami, Cet ke 16, Bandung: Penerbit PT Refika Aditama.

Missmelind, 2011. Pengaturan kondisi dan penciptaan klim belajar yang menunjang.http://missmelind.blogspot.com/2011_03_01_archiv e.html. diakses tanggal 4 November 2019

Nawawi, Hadari. 1989. Organisasi Sekolah dan Pengelolaan Kelas, cet. 3, Jakarta: CV Haji Masagung.

Rachman, Maman. 1998. Manajemen Kelas. Jakarta: Departemen Pendidikan dan Kebudayaan Direktorat Jenderal Pendidikan Tinggi.

Sudirman N, dkk. 1991. Ilmu Pendidikan, Bandung: Remaja Rosdakarya.

Saefullah. 2014. Manajemen Pendidikan Islam. Bandung: Penerbit CV Pustaka Setia. 